\title{
Internal Migration and Poverty Reduction: Rethinking the Debate on the North-South Movement in Ghana
}

\author{
${ }^{1}$ Richard Serbeh, ${ }^{2}$ Prince Osei-Wusu Adjei and ${ }^{3}$ Thomas Yeboah \\ ${ }^{1,3}$ Centre of Development Studies, University of Cambridge, UK \\ ${ }^{2}$ Department of Geography, Kwame Nkrumah University of Science and Technology, Ghana
}

Article history

Received: 28-04-2015

Revised: 29-05-2015

Accepted: 28-10-2015

Corresponding Author:

Thomas Yeboah

Centre of Development Studies,

University of Cambridge, UK

Email: ty268@cam.ac.uk

\begin{abstract}
In the past few years the nexus that link internal migration and poverty reduction has been a subject of interest among researchers and policy makers. Internal movements constitute a major coping mechanism in poverty stricken areas although the evidence supporting this claim is equivocal. This paper critically examines the extent to which internal migration could acts as an important route out of poverty in areas where conventional poverty reduction policies have failed by drawing on empirical literature on the north-south movement in Ghana. We argue that internal migration may not be a silver bullet in the fight against poverty. This position is premised on two strands of thought. First, migrants may not always be able to improve upon their livelihood, earn income and leap-out of the malaise of poverty and the impact of remittances may not also be straightforward. Secondly, the very poor in the places where conventional development efforts have had limited success may not always have the wherewithal to move as migration is shaped inter alia by institutional, market and financial resources.
\end{abstract}

Keywords: Internal Migration, Ghana, North-South Movement, Poverty, Remittances

\section{Introduction}

Migration and poverty reduction have become one cardinal policy issue in developing countries. Due to the fact that many rural communities are left behind in relation to benefitting from the process and outcomes of development, a huge number of people cross regional and provincial boundaries in search of alternative livelihood sources. Although internal migrants far outnumber international migrants, scholarship in the migration field seems to have focused much attention on international migration. This is perhaps due to the increasingly huge amount of remittances from international migrants to their home countries and its implications for poverty and human development. The 2009 Human Development Report for example revealed that the number of internal migrants globally is 740 million, a figure which is four times that of international migrants (MPRPC, 2011). In China for example, 15 million rural dwellers move to urban areas each year and with the growth of the economy, this figure is expected to appreciate (UN, 2005 cited in IOM, 2005). Similarly, in India, internal migrants run into millions while international migration is only a small fraction (Srivastava and Sasikumar, 2003). In Vietnam people moving internally constituted 4.3 million compared to fewer than 300,000 international migrants before the census in 1999 (Anh et al., 2003) In sub-Saharan Africa, an estimated $50-80 \%$ of rural households has a conspicuous link with at least one internal migrant member (Deshingkar and Grimm, 2005). While making generalizations of the levels of internal migration is complicated on the basis of few case studies from developing countries on internal migrants, there is compelling evidence to suggest that neoliberal stabilisation and adjustment policies that were implemented in the 1980s under the auspices of the Bretton Wood institutions has engendered high mobility flows of people living in rural economies who seek to diversify their livelihood portfolios and thus move to nearby trade and buoyant economies (Deshingkar and Grimm, 2005). Thus there is a persuasive argument for analysing the nexus of internal migration and poverty reduction in specific local context. 
Most studies have shown that internal migration has some positive implications for poverty reduction (Castaldo et al., 2012; Ping and Shaoua, 2005; Deshingkar and Grimm, 2005) although others (for example Dang, 2003) see it as counter-productive. Following this line of argument, there is an emerging academic and policy debate about whether internal migration should be used as a conventional poverty reduction tool. For instance, while Ping and Shaohua (2005) argued that internal migration has a positive poverty reduction impact on the rural poor in China, Adams (2006) expresses a contrary view.

The objective of this paper is to add to this emerging debate by arguing that internal migration may not be a silver bullet for poverty reduction hence should not be relied upon as a potent weapon in the war against poverty due to the fact that the relationship between migration and poverty reduction may be context specific with outcomes contingent on local circumstances and situation. Our argument is premised on two strands of thought. First, migrants may not always be able to improve upon their livelihood, earn income and leap-out of the malaise of poverty while the impact of remittances may also not be significant and straightforward. Secondly, the very poor in the places where conventional development efforts have had limited success may not always be able to move as migration require inter alia the necessary institutional, market and financial resources. To address these concerns, the paper focuses on the north-south migration in Ghana which according to Grant and Nijman (2004) is the outcome of biased and limited impact of development polices. The paper contributes to the growing body of literature that has highlighted the impact of underdevelopment and poverty as well as the need for policy initiatives that specifically target underserved rural economies where poor livelihood outcomes and precarious socio-economic conditions have engendered high migratory flows.

Following these introductory comments, the paper proceeds to section two to provide a sketch of the theoretical debates on migration-poverty reduction linkages. A brief socio-economic context of the northern regions where migrants originate will be outlined. We then provide the trends and dynamics of internal migration in Ghana with specific emphasis on the northsouth movement. The next section analyses the linkages between the north-south migration and poverty reduction at the household and individual levels before a conclusion is drawn in the last section.

\section{Migration-Poverty Reduction Nexus: What Does The Theory Say?}

The impact of migration on development and by implication poverty reduction has been the subject of debate over the past four decades. At the heart of these debates are two dominant and opposing schools of thought namely: The balanced growth and asymmetric theories- popularly known as migration optimists on the one hand and pessimists on the other (de Haas, 2010).

\section{Migration Optimists Versus Pessimists}

Largely inspired by neoclassical migration economic and developmentalist modernisation theories, optimists have argued that migration is positively related to poverty reduction. Proponents of the neo-classical migration economy perceived movement of labour as a form of optimal allocation of productive factors in both sending and receiving regions (de Haas, 2010). Implicit in this theorization, proponents convey the idea of a winwin situation for migrant origins and destinations as labour move from capital scarce to labour scarce regions and capital flows in the opposite direction. The reallocation of labour from rural, agricultural societies to urban and industrial societies is therefore perceived as a major component of the development process. The net effect of this movement is factor price equalization through which the developmental role of migration is achieved. Accordingly, movement of labour ceases once wages at migrant origins and destinations converge (de Haas, 2010).

Despite its assertiveness, largely absent from the neoclassical perspective as de Haas (2010) has shown is the role of remittances because migrants are divested of their social responsibilities towards the families, households and communities. By assuming away such responsibilities, no place is found for remittances in the neoclassical school on labour migration. Contrary to this, the developmentalist theorists perceive migrants as important sources of change and innovation whose remittances play crucial role in local level development. Unlike the neoclassical view which was largely silent on remittances, developmentalists argue that such transfers constitute an important tool in bridging income disparities and ensuring qualitative improvement in standards of living (Keely and Tran, 1989 cited in de Haas, 2010).

These so-called benefits therefore influenced the implementation of policies to encourage mass out migration in countries such as Philippines. From the late 1960s however, this benign optimism invested in migration came under severe criticism largely by dependency theorists. Drawing on structuralist social and dependency theories, critics argued that migration is less effective in solving the structural conditions that prompt mobility. While taking cognisance of the role of remittances, proponents expressed concerns about the effects of brain drain on sending societies (Baldwin, 1970). By depriving developing societies of skilled human resources, migration to a larger extent was 
detrimental to the process of development. In consequence, the income equalising principle hailed by "migration optimists" was discredited as naïve and lacking any empirical validity. Migration was rather a major contributory factor to the rising levels of income inequality in sending societies. In consequence, the 1970s saw a boom in academic publications which identified migration as a cardinal factor contributing to the development of underdevelopment (de Haas, 2010; de Haan and Yaqub, 2009) and thereby contradicting the basic assumption of migration optimists. Unlike neoclassical interpretations which identified modernization as the inevitable outcome of migration, the structural and dependency views identified underdevelopment and pauperization of migrant origins as the end result of migration. To reverse this trend, Third world (peripheral) countries therefore needed to control and restrict the movement of labour to core countries. Asymmetric growth became a central theme of the pessimist perspective unlike factor price equalization which was believed to be the avenue through which the developmental role of migration could be unleashed by the optimists. These so-called negative perspectives on the role of migration as de Haas (2010) has shown, crystallised into what became known as "migrant syndrome", a process which depleted rural areas of valuable and priceless human capital resources needed for development. These theoretical assumptions have been justified by some empirical studies which have found that due mainly to the selectivity effect, migration has a predilection for the skilled, active, more entrepreneurial and better educated people which logically suggest that a continuous movement of labour from rural (peripheral) to urban (core) areas which has the potency to worsen the misery and condemn migrant origins to perpetual deprivation. Furthermore, Lipton (1980) study subjected the remittance debate to empirical refutation. As Lipton argued, $90 \%$ of remittance was spent on everyday consumption which illustrates that the investment potentials of migrants may be a fad in its own right. Despite its strong appeal particularly in developing countries, these pessimist views conceptualise migrant origins as closed societies, an assumption which may lack an empirical justification. In proposing cutting off ties with the outside world, proponents seem to convey the idea of equal resource endowment across societies which may not be practically accurate.

\section{The New Economics of Labour Migration}

Towards the second half of the 1980s, these extreme opposing views gave way to pluralist perspectives which considered agency and structure as important variables in the migration-development debate (de Haas, 2010). The main contribution to the pluralist thought came from the
New Economics of Labour Migration (NELM) theory. Proponents argued that the basic assumptions of neoclassical models are rigid and less likely to address the complexity of factors characterising the migration and development nexus. By placing individual agency in a wider sociocultural context and considering the household as an important unit of analysis (de Haas, 2010), NELM showed that the decision to migrate falls outside the realm of individual decision making. Labour migration is thus perceived as a risk sharing behaviour and a livelihood diversification strategy for poor households (de Haan and Yaqub, 2009). Thus the supposed benefits to households in the form of remittances and transfer of skills played a crucial role in recommending migration to particular members of the households (Stark, 1991 cited in de Haan and Yaqub, 2009) because this may represent a Pareto superior strategy. The NELM together with the livelihood strategy (which viewed migration as a means to acquire assets to insure against future stress and shocks; de Haan and Yaqub, 2009) theory, marked a departure from the atomistic individual who in the neoclassical thought was divested of all social relations to an individual whose decision to migrate stemmed from wider sociocultural context.

From the analysis, it may not be possible to examine the migration development nexus without reference to the underlying structural factors influencing the movement. The opposing theoretical perspectives further show that perhaps it may be simplistic to subject the nexus to single factor explanations since migration is characterised by complexity of factors ranging from the micro to macro level. This therefore warrants an empirical analysis of these linkages in order to clarify the relationship between migration and development. In the next section we draw on case of Ghana to show whether migration could be used to serve as tool for poverty reduction in places where conventional development efforts have had limited success.

\section{Setting the Context for Migration: Socio- economic and Poverty Conditions of Northern Ghana}

Northern Ghana which serves as context and origin of migrants in this study includes the Upper East, Upper West and northern regions. The entire region is covered by Savannah with poor endowment of natural resources (Marchetta, 2011). Economically more than $70 \%$ of the active labour force of northern Ghana is engaged in agricultural activities including food crop farming, livestock rearing and agro-processing (GD, 2012). Several communities in this region face acute water 
shortage and floods. The progressive environmental changes that are occurring in these regions affect the main livelihood source-agriculture-of the inhabitants. Certainly, the prolonged drought experienced in the savannah belt together with increasing variability of rainfall patterns expose farmers to high risks of crop failure and loss of livestock, resulting in significant loss in productivity (Assan et al., 2009; Hesselberg and Yaro,2006).

As will be explained further in the next section of the paper, these environmental conditions have combined with colonial and post-colonial policy dispensations in intensifying the poverty, vulnerability; and hardships for majority of people in northern Ghana. Thus despite the significance of agriculture as the mainstay of the northern economy, a plethora of empirical studies have demonstrated increasing levels of diversification into non-farm activities and migration to the southern cities (Assan et al., 2009; Yaro, 2006; GSS, 2005; Yeboah, 2005).

Ghana recorded an impressive decline of poverty (from $51.7 \%$ in $1991 / 1992$ to $28.5 \%$ in $2005 / 2006$ ) (GSS, 2007). Although an impressive feat, regional trend showed that the success in poverty reduction has unevenly been distributed and thus varies among the geographical regions of the nation. Between the period of 1998/1999 and 2005/2006, Central and Eastern regions experienced the most significant reductions in poverty- 48 to $20 \%$ and 44 to $15 \%$ respectively (GSS, 2007). Ashanti region had about $8 \%$ reduction-that is from 28 to $20 \%$. Poverty reduction was not much significant in the northern regions. Majority of Ghana's poor is thus mainly concentrated in the Northern part (Northern region, Upper East region and Upper West region) of the country. While the incidence of poverty is about $12 \%$ in Greater Accra and $20 \%$ in Ashanti region, Northern, Upper East and Upper West regions have about 52,70 and $88 \%$ respectively (GSS, 2007).

Income per capita of households in northern Ghana is far below the national average and that of other regions of the south. Recent statistics from the GSS (2014) suggest that Ghana has a mean annual average household income of $\mathrm{GH} \notin 16,644.6$. However there are large regional disparities with Ashanti and Greater Accra recording $\mathrm{GH} \notin 22,199.5$ and $\mathrm{GH} \notin 16,580$ mean annual average household income respectively whereas the Upper East, Upper west and Northern region have a mean annual average household income of $\mathrm{GH} \notin 7,240, \mathrm{GH} \notin 11,977.5$ and $\mathrm{GH} \phi 12,281.4$ respectively (GSS, 2014).

Thus poverty is disproportionately experienced by the northern population. Apart from low agricultural income, other dimensions of poverty experienced by the northern population include unemployment, lack of access to safe drinking water and sanitary facilities which can boost human survival, malnutrition, ill-health, low educational attainment, social exclusion and food insecurity. These different elements as Bhasin and Annim (2005) argue interact and keep households in persistent and deeper poverty. Despite compelling policy initiatives such as the school feeding programme and education capitation which has abolished school fees, evidence has it that about $40 \%$ of young people mainly females of school going age in the Northern regions are not enrolled in school due to the inability of parents to cover other school related expenses such as transport and buying of school materials (WB, 2011). The challenge of food security is a major dimension of poverty in northern Ghana. According to a study by the WFP (2013), in Ghana a national average of $5 \%$ of the population is recorded as food-insecure. However, there are large regional disparities, with a high ratio $-34 \%$-of food insecurity among the population in the Upper East Region, whereas it is $15 \%$ in the Northern region and just $1 \%$ for Greater Accra Region. In effect the environmental, political and socio-economic difficulties confronting the livelihoods and living conditions of the population of northern Ghana compel majority of them to seek alternative survival strategies. Without doubt, migration to the buoyant southern economy therefore presents itself as a key diversification strategy for most households. The next section looks at the trends and dynamics of internal migration in Ghana.

\section{Internal Migration in Ghana: Trends and Dynamics}

With reference to the source and destination of movement, internal migration in Ghana can be classified into four categories: Rural-urban, rural-rural, urban-rural and urban-urban migration (GSS, 2008). These trends have a long history traceable to the pre-colonial era when movements were premised on the search for farm lands, security and trading partners (Wouterse, 2010; Awumbila et al., 2008). Internal movement continued during and after colonial rule but have been influenced by the nature of development policies. Policies biased in favour of the urban and southern Ghana have resulted in unequal development between urban and rural areas and the southern and northern parts (Northern, Upper East and Upper West regions) of the country respectively (Arthur, 1991). Allen (1979; cited in Arthur, 1991) for example argued that $80 \%$ of all development initiatives (infrastructure and industry) are located in and around Accra, Kumasi and SekondiTakoradi (cities in southern Ghana).

These spatial inequalities, coupled with the limited impacts of poverty reduction policies (Ghana/Growth and Poverty Reduction Strategies I and II) have led to high levels of unemployment, poor infrastructure and inadequate social services in the three northern regions. 
As mentioned earlier poverty reduction has not been significant in the three northern regions. This has resulted in a mass out-migration (mostly the youth to Accra, Kumasi and Sekondi-Takoradi) popularly referred to as the 'north-south migration' (Awumbila and Ardeyfio-Schandorf, 2008: 171). The lack of jobs and poor living standards have thus rendered the northern part of Ghana a major source of unskilled labour for the buoyant southern economy (Awumbila and Ardayfio-Schandorf, 2008). In 2007 for example, $97 \%$ of female head-porters in Accra were migrants from the Northern, Upper East and Upper West regions (Awumbila et al., 2008). The economic reason underpinning the north-south movement is evident in this assertion by a female migrant in a study by Yeboah (2008: 141):

\section{We come here to work because there are no profitable works to do back home in the north and we cannot watch our children starve and die of hunger... I can say that we have exhausted all the means of survival in the north and we do not have any other option than to come to Accra and work for money. Things have become really difficult for us as women.}

The north-south movement thus displays a characteristic of the neoclassical theoretic framework where labour movement is in response to differences in income between locations (de Haas, 2010). Though economic reasons are critical factors underpinning this movement (Anarfi, 1993; Arthur, 1991, Awumbila et al., 2008), the search for better social services such as good drinking water, electricity, hospitals and educational facilities also influence this drift (Awumbila et al., 2008; Caldwell, 1968).

Recently, the male dominated north-south drift has assumed a dramatic shift with females and children joining this seemingly endless movement (Awumbila et al., 2008; Awumbila and Ardeyfio-Schandorf, 2008; Anarfi and Kwankye, 2005; 2009). For such migrants, the dream of entering the southern industrial enclave appears to be a facade upon arrival and to cope with the realities of urban life, the informal economy becomes their major employer, where they engage in menial jobs such as 'chop bar' (local restaurant) attendants, shop assistants and heavy load carriers (Awumbila et al., 2008). Figure 1 shows the flow of migrants from northern to southern Ghana.

It is evident in Figure 1, that females constitute a majority of the migrants involved in the north-south movement accounting for 50, 70.2 and $80.9 \%$ of migrants from the Upper East, Northern and Upper
West regions respectively. This represents a major shift in the observed trends in the past when women usually accompanied their husbands in the migration stream. The corresponding figures for their male counterparts are $50 \%$ from Upper East, $20 \%$ from Northern and $11.1 \%$ from Upper West regions. Although all the arrows converge in Accra, Kumasi is home to majority of migrants and also serves as the nodal point in the journey to Accra.

\section{Internal Migration as a Strategy for Poverty Reduction: Evidence from Ghana's North- South Migration}

\section{Characteristics of Migrants}

Before going into the main issue of the paper, it will be useful to capture briefly the socioeconomic characteristics of the migrants' in southern Ghana. Literature on the background characteristics of internal migrants in Ghana shows that contemporary north-south migration flow is largely dominated by young girls and women in their reproductive years, who end up in occupational niches largely classified as undesirable with many having little or no education (Yeboah et al., 2015; Shamsu-Deen and Alhassan, 2014; Awumbila and Ardeyfio-Schandorf, 2008). Among a sample of 400 migrants, Shamsu-Deen (2013) found that the age range was 10 to 30 years with majority of them falling within the age bracket of 13 to 25 years. They reported that $86 \%$ was between the ages of 10 to 25 years while the remaining $16 \%$ was 25 years and above. Similarly, Agyei et al. (2015) demonstrated in their survey that many of the migrants in southern Ghana are in their youthful stages with majority falling within the ages of 12-35years. Indeed migration often increases with age, though at a decreasing rate, which highlights the selectivity of population flows on economically active age group (Agyei et al., 2015). The age distribution of northsouth migrants support the assertion made by some scholars that migration is fundamentally positioned in the youthful stages of lifecycles (Huijsmans, 2008).

In terms of education, most of the migrants in southern Ghana have not had opportunity to attain formal schooling beyond secondary level. While the relevance of school completion has been recognised to be an imperative determinant of future earnings and the returns that the individual derives from education, Shamsu-Deen (2013) demonstrates that about half $(50 \%)$ of 400 migrants has not had the opportunity to enrol in any formal education with about 27 and $19 \%$ having primary education and Junior High School education respectively while $2 \%$ each had attained vocational education. 


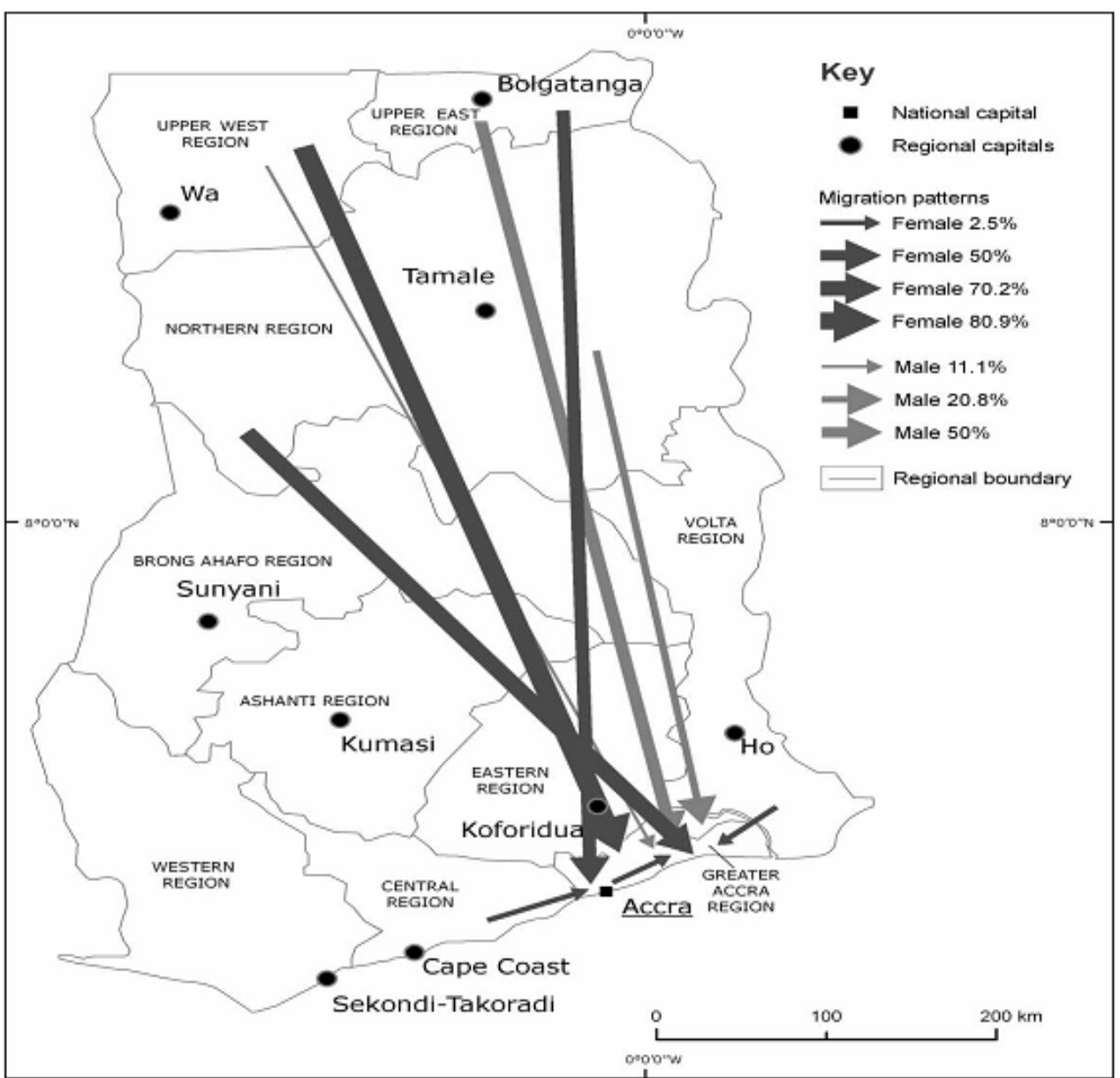

Fig. 1. Map of Ghana showing the North-South movement (Awumbila and Ardeyfio-Schandorf, 2008: 17)

Likewise, Awumbila and Ardayfio-Schandorf (2008) found a total of $61 \%$ of migrants having no formal education with $35 \%$ having primary education while only $5 \%$ has attained Junior High School education. A number of studies have also recorded low levels of education among north-south migrants in Ghana (Agyei et al., 2015; Anarfi and Kwankye, 2005; Opare, 2003).The lack of higher formal educational attainment among the migrant population is largely attributed to lack of financial resources needed to cover school related expenses.

Poverty among migrants in southern Ghana manifest in poor working conditions, inadequate access to healthcare and decent housing. Kwankye et al. (2007) report low incomes, indecent shelter, exploitation by clients and harassment from city guards and difficult nature of work as the major dimensions of poverty associated with north-south migrant population. Similarly Quaicoe (2005) has demonstrated poor housing facilities, poor health care, inadequate sanitation facilities and sexual harassment as the major dimensions of poverty among female migrants in Ghana.
Fundamental to the poverty conditions facing migrants is the lack of decent accommodation. Yiran et al. (2014) found that more than $94 \%$ of a sample of 100 migrants subsists in abandoned wooden structures that are smaller than standard single bedroom due to the challenge of high rental charge by landlords for decent accommodation in Accra. Although the average room occupancy as stipulated in Ghana's national housing policy is two persons per room (UN-HABITAT, 2011), among a sample of 100 female migrants, BaahEnnumh et al. (2012) discovered that $49 \%$ of migrants were leaving in wooden shacks, shops and verandas and in slums with average room occupancy rate of 4-5 persons. In sum difficulties associated with working conditions, housing and lack of access to existing social services are key dimensions of poverty experienced by north-south migrants.

\section{Internal Migration and Remittances}

As noted earlier in section two, a major pathway through which internal migration leads to poverty reduction is remittances (Ackah and Medvedev, 2010; 
Awumbila et al., 2008). Ackah and Medvedev (2010) have shown that remittances to the north constitute $11 \%$ of household income. Remittances usually are invested in family businesses to provide security against unforeseen circumstances hence minimising the fear associated with insecurity. Moreover such transfers provide households with the means of accessing their basic needs. Remittances, Ackah and Medvedev (2010) argue, provide an escape route out of grinding poverty through enhanced access to health, education and food in poor households. These intended benefits may therefore account for the pooling of resources to finance the migration process (Arthur, 1991). In a DFID sponsored study, Castaldo et al. (2012) revealed that between 2007 and 2008, the Northern, Upper East and Upper West regions received internal remittances amounting to $\notin 324$ billion, $\notin 26.4$ billion and $\notin 26.4$ billion (USD 35 million, USD 2.9 million and USD 2.9 million) (Exchange rate in 2006: USD1 $=\varnothing 9,200$ (Castaldo et al., 2012). Figures are in Old Cedis (ф)) respectively. These transfers are believed to open the way to a qualitative transformation of life by equipping the poor to free themselves from deprivation. This argument is grounded in the rational rubric that money in the hands of the poor will always ensure consumption smoothing leading to a better change in standards of living over time.

Though a benign argument, it has never suffered a dearth of criticism. In assessing the impact of remittances on welfare, careful consideration should be given to the amount of money involved, the frequency and uses of such transfers. To begin with, critics argue that remittances to the three northern regions are woefully inadequate to achieve any meaningful impact on households (Adams, 2006). Contributing only $11 \%$ to family income (Ackah and Medvedev, 2010), the perceived role of remittances in weakening poverty may be a fad in its own right. In Castaldo et al. (2012) estimation, the three northern regions in 2007 and 2008 accounted for only $12.7 \%$ of total internal remittances in Ghana, a figure which is nearly half the amount received by Ashanti region ( $\varnothing$ 615billion $(21 \%)$ ) within the same period. This trend is reinforced by migrants' meagre incomes as revealed by Awumbila and Ardeyfio-Schandorf (2008). In their study, only two female head porters out of a total of hundred migrants interviewed earned between USD 45 daily with the remaining earning less than this amount. Considering the depth and incidence of penury, remittances may fall short of expenditure hence the so-called anticipated effects on poverty may be a fallacy. Accordingly, Adams (2006) posited that, adopting the head-count measurement of poverty, internal remittances in Ghana reduced poverty only by $2 \%$ while the poverty gap measurement saw a slight improvement of $4.1 \%$ reduction. These findings obviously may unsettle the logical foundations underpinning the poverty reduction impact of remittances in these three northern regions.

This problem is further compounded by the fact that migration is self-selecting and thus remittances may not flow to the poorest of the poor. Although we take cognisance of the fact that the very poor may finance their migration through borrowing, empirical research shows that the absolutely poor may not always have the wherewithal to migrate because migration requires some amount of capital, social and family support which they may not have readily (Wouterse, 2010; Ackah and Medvedev, 2010; Awumbila et al., 2008). The relatively less poor in the north thus are able to move which logically suggests that the flow of remittances goes not to the families of the very poor. Arithmetically then, it may be estimated that with about $80 \%$ of people in these three regions in poverty and $70 \%$ of this number in absolute poverty (GSS, 2007) only $10 \%$ may be likely to receive remittances, an outcome which shows a narrow coverage of remittances among the poor.

Hesselberg and Yaro (2006) further argue that uncertainties such as difficulty in securing jobs and exploitation bedevilling the north-south movement affect the frequency with which remittances may be sent home. Most migrants find it difficult securing jobs and even when they do, their meagre incomes make it difficult to remit their families regularly (Awumbila and Ardayfio-Schandorf 2008). The scarcity of jobs for example has resulted in severe competition in the 'Kayayo' (head-porters) business. In consequence the continuous movement of unskilled migrants to the urban centres without a corresponding increase in the demand for their services therefore pose a threat to migrants' earning and may have a direct impact on remittances. Under such conditions, Say's Law which states that supply creates its own demand (Bateman and Chang, 2012) may not hold, resulting in severe consequences for migrants. By implication, it could be argued that even if the north-south migration may have some benefits for some migrants, it may not be beneficial to the large numbers of young people trouping into the southern part of the country, a condition which is indicative of the fallacy of composition. The saturation of the market for porters and the resultant competition is better expressed by a female porter in Awumbila and Ardayfio-Schandorf's (2008:174) study when she claimed:

When I began coming to Accra four years ago, there were only five of us here in Tudu... but now there are hundreds of us and the competition to carry goods has become keen. 
Under such circumstances, migrants' families may receive remittances irregularly which may insignificantly improve living standards. This perhaps supports Ackah and Medvedev's (2010) claim that irregular remittances worsen living standards of remittancedependent households. Thus considering the resources that may have been pushed into sponsoring migrants vis$a$-vis the outcome, the north-south movement may end up being a bad investment in the long run.

Furthermore, critics are of the view that remittances may not necessarily be tailored towards poverty reduction initiatives and consumption (Awumbila and Ardeyfio-Schandorf, 2008). Empirical evidence suggests that remittances from young female migrants are spent on making the necessary preparations for marriage ceremonies (Awumbila and Ardeyfio-Schandorf, 2008, Yeboah, 2008). In Opare's (2003) study for example, it was observed that approximately $55 \%$ of respondents migrated in order to earn money for their wedding ceremonies. Under these conditions remittances may not be used to purchase the right bundle of goods having a direct impact on the incidence of poverty. It is therefore evident that remitting families to fight poverty may not always be the most preferred choice for young migrants engaged in the migration stream. The following comment by a female migrant in Yeboah's (2008: 144) study is illustrative of the forgoing argument:

\section{I only came to Accra to work and save money to buy the things I need for my wedding. I have been betrothed to a man in my village but my parent cannot pay for the wedding expenses which they are supposed to pay. They are supposed to buy cooking ware, clothes, shoes and also give me a sum of money so that I can take with me to the marriage. My parents cannot afford to do that so they decided that I should come to Accra and work to buy those things as most other girls from my village do.}

Consequently, Hesselberg and Yaro (2006) in their study in the Kasena Nankana District of the Upper East region documented that $61 \%$ of households receiving remittances did not consider such transfers as important source of livelihood entitlement. We take cognizance of the fact that the nature of north-south migration pattern, the specificity and the selectivity of the north-south migration stream all have far reaching implications in determining the pattern of remittances in the country.

From the discussion, hardly can it be accepted that remittances do have any significant impact on poverty reduction. Even if it does, the argument shows that it may be usually restricted to the less poor. This perhaps reinforces Lipton's (1980) assertion that the selective nature of migration leads to higher returns for the less poor as compared to the absolutely poor. It therefore would be inappropriate to view the north-south movement as a way out of poverty since its benefits in terms of remittances show a more nuanced outcome as well as limited degree of distribution.

\section{Internal Migration and Skills Acquisition}

Added to the impacts of remittances, internal migration has been identified to provide opportunities for migrants to be equipped with new skills and abilities (Ackah and Medvedev, 2010; Arthur, 1991). Moving to the south, it is argued that migrants receive new skills which enable them contribute to local development (Ackah and Medvedev, 2010). The rationale underlying this argument is that migrants with new skills may help change the phase of agricultural and institutional structures in most of these societies (Arthur, 1991). Returnees may for example offer informal education to the local people especially farmers lacking access to formal agricultural extension services. Furthermore many returnees establish small scale businesses to diversify livelihood sources and with time, the benefits from such enterprises may trickle-down to other members of returnees' households and the wider society.

Arthur (1991) moreover argues that returnees provide leadership roles and help in the formation of political consciousness among the people. The poor's inability to hold leaders to account and demand equitable resource allocation is known to be predicated on their voicelessness (Narayan et al., 2000). Returnees in the view of Arthur (1991) fill this void by mobilising the poor to demand accountability from local leaders. Having been in contact with vibrant political processes in the south, returnees may lead campaigns for pro poor policies in poor rural areas (Wouterse, 2010). This genial postulation was catapulted to great heights on the eve of Ghana's implementation of the District Assembly concept which was believed to be the framework within which local needs were to be articulated (Wouterse, 2010).

Regardless of how assertive adherents of this view may be, empirical evidence differs markedly from their conviction. Tellingly, the skills migrants acquire from menial jobs (Awumbila et al., 2008) may be of limited relevance to their home regions. Until proponents of this view prove that skills acquired through carrying heavy loads, selling dog chains and washing plates at chop bars (local restaurants) may be successfully brought to bear on agriculture (the main stay of the northern economy), this argument remains flawed. It may thus be argued that migrants may have very little to offer in terms of local level development. Moreover, Lipton (1980) insisted that returnees are usually the 
weak, sick and unsuccessful hence obscuring any prospect of contributing to the local economy significantly. Rather, returnees may end up becoming financial liabilities on the poor, exerting pressure on the already overburdened and insufficient household budget. Moreover regarding the establishment of small scale businesses, recent evidence by Bateman and Chang (2012) have shown that such ventures may not be sustainable in the long term because they operate on small scale and therefore may not provide the needed potency to lift the poor out of poverty. The inability of such enterprises to produce and enjoy economies of scale thus constitutes an affront to viable long term poverty reduction efforts. Thus while not discounting the nobility behind the establishment of such "tiny ventures", there is relatively very little reason to assume that they can offer long term solution to the depth and incidence of poverty which drives the north-south movement.

Politically, studies have shown that District Assemblies in Ghana have been less successful in involving the local people in policy formulation because local policies are designed and implemented by foreign donors and the central government (Aryee, 2000; Crawford, 2004; Ribot, 2001). Though local authorities are physically present in remote areas with their offices exerting an unrivalled dominance over the rural landscape, in terms of policy making and implementation, this presence may not be felt. Thus contrary to the so-called bottom-up approach to policy formulation and implementation inherent in Ghana's decentralisation policy, practically, local level development has not been weaned off the control of the central government. The outcome is that the leadership roles accorded returnees by Arthur (1991) may not affect the outlook of poverty reduction initiatives since policies are neither designed nor executed by local authorities but rather by paternalistic foreign donors and the central government domiciled in Accra.

\section{Internal Migration and Productivity}

Internal migration is also famously known to reduce pressure on farm lands (Ackah and Medvedev, 2010). This argument is premised on the assumption that since agriculture is the mainstay of the northern economy, access to land may increase productivity and subsequently empower the poor in their fight against poverty (Hesselberg and Yaro, 2006). Confronted with fragmented and small land holdings due to high agricultural density, the poor are not able to expand farm sizes to increase production hence their reliance on subsistence production. The north-south movement is therefore seen as a way of overcoming this dilemma since the movement reduces the agricultural density thereby making land readily available to the few who are left behind to engage in large scale production (Mensah-Bonsu, 2003). Productivity increases thus may lead to a corresponding rise in household income and perhaps paves the way for the poor to access their needs.

Per contra, the outcome of the north-south movement deviates from this logic. As explained by Hesselberg and Yaro (2006), it is unlikely farmers will cultivate freed lands due to the limited capital to employ additional labour and purchase new inputs. Desirable as expansion of farm sizes may be, budgetary constraints may render farmers helpless, thereby restricting them to subsistence production (Hesselberg and Yaro, 2006). Proponents of the productivity debate are quick to rebut by retorting that this problem can be solved by borrowing from financial institutions. Though a noble proposition, it so happens that access to loans is beyond the reach of these poor farmers as a result of their inability to provide collateral security (Addae-Korankye, 2012). It is obvious that with the financial outlays involved in farm expansion, most farmers may remain passive and unconcerned. Consequently, Hesselberg and Yaro (2006) showed that though families may have freed lands, their poverty barred them from using such lands. Moreover, Arthur (1991) argues that out-migration of the active labour force coupled with the ageing of the remaining population pose a serious threat to productivity because of the shortage of labour. Thus even if lands are freed, the old men and women may not be able to cultivate such lands to increase productivity. It is therefore obvious that the north-south movement may rather threaten food security in these regions. Having looked at benefits for migrants' origins, the paper now takes a look at the success of the north-south movement in improving migrants' lives.

\section{Internal Migration and the Welfare of Migrants}

Caldwell (1968) in an early study of the dynamics of internal migration in Ghana argued that migrants, upon settling in Accra, Kumasi and Sekondi-Takoradi are able to access social services that may be unavailable in their localities. Good drinking water, electricity, education and access to health centres are cited as range of social services migrants enjoy which in the long run improve their welfare. Thus migration may be seen as a way of compensating for their neglect in the provision of such services. However, do migrants always have access to these facilities?

\section{Does Movement Improve Incomes?}

In assessing the impact of movement on migrants, it is imperative to make reference to the income status of migrants. This does not however constitute an attempt to justify income as the single most important factor determining an improved or otherwise standard of living but it may help ascertain the extent of migrants' 
access to social services. Table 1 shows migrants' daily incomes in a study conducted by Awumbila and Ardeyfio-Schandorf in the Accra Metropolis.

From Table 1, it is evident that the highest income migrants earned daily is between $\$ 40,000-\varnothing 49,000$ (USD4-5) $(\notin 10,000=$ USD1.20 (Awumbila and Ardeyfio-Schandorf, 2008)) with majority earning below this amount. Females earned the lowest incomes with approximately $2 \%$ able to make the highest income which logically indicates that access to some social services may be a luxury as compared to their male counterparts who are similarly not much better off. Moreover approximately $9 \%$ of migrants had incomes determined by the distance over which loads were carried. It is imperative to note that, such incomes usually may be a reflection not of the distance covered but the shrewdness of customers. Moreover at the heart of the lower earning capacity of north-south migrants is the incidence of exploitation. In the case of minors, the demand of the local culture which requires deference and compliance from the younger generation without protestation robs young porters for example of their bargaining right which consequently subject them to receiving pittance from the services rendered to clients. A gendered dimension of the exploitative tendencies is that women receive lower fees for their services as compared to their male counterparts though it must be emphasised that clients usually prefer women to men in transporting their goods (Yeboah, 2008). These exploitative tendencies are made possible by the lack of an institutional mechanism which could regulate migrant-client relationships.

\section{Internal Migration and Access to Social Services}

Due to their meagre incomes, migrants' access to most social services may severely be curtailed. In Agbobloshie (a notable migrant community in Accra) for example, migrants due to their inability to rent descent accommodation settle in make shift structures where a room, in addition to serving as a storage for personal belongings such as cookware and canisters usually accommodate between six to ten people (Yeboah, 2008). Such slum and shanty areas, Nukunu (2013) argued, have gained notoriety for insanitary conditions, higher crime rates, poor social services and drainage systems which put migrants' well-being at risk. Accordingly, Songsore and MacGranahan (1993) identified malaria to be the most highly reported disease at health centres located in these areas exposing migrants to severe health risks. The periodic outbreak of diseases such as cholera in these areas pays tribute to the myriad of health problems facing migrants in these communities. For those unable to rent rooms and kiosks, sleeping in open spaces, at bus stops and on pavements becomes the norm (Nukunu, 2013; Anarfi and Kwankye, 2005) exposing them to physical and sexual harassment. This condition is revealed by no better assertion than the following evident in Awumbila and ArdeyfioSchandorf's study in Accra (2008:178):
At night thieves come to harass us and if others try to rape anyone of us, the victim shouts and we all get up and hit the thieves with our pans and they run away.

Implicit in this assertion, migrants' ability to attack with aluminium pans (their most valuable income generating asset) becomes the only assurance of salvation under such gruesome conditions, a situation which reflects their insecurity. Yeboah (2008:153) found that where migrants are unsuccessful in defending themselves against sexual harassment, they resort to "making money out of it" as evident in this assertion:

\begin{abstract}
Some of these women engage in prostitution when they come to Accra... Their reason for doing that is that...men harass them for sex and some even rape them so instead of letting the men have it for free, they will rather sell it to make money out of it.
\end{abstract}

\section{Internal Migration and the Health of Migrants}

Besides, Anarfi (1993) has argued that in the migration discourse, epidemiological concern should be focused on: The possible transmission of diseases by migrants and their exposure to diverse health hazards in the course of movement and at destinations. The tendency of infecting and being infected thus becomes the upshot of movement and may be exacerbated by the absence of policies that minimise susceptibility to such infections. Unlike international migrants who are screened for diseases and are subsequently vaccinated, there are no such measures to reduce the risk of infection among internal migrants. The insecure atmosphere and the subsequent engagement in prostitution by some northsouth migrants expose them to health hazards which endanger their lives (Yeboah, 2008).

Table 1 . Migrants' daily incomes

\begin{tabular}{lcc}
\hline Daily wage & Male (\%) & Female (\%) \\
\hline Less than 10,000 & 9.7 & 8.1 \\
10,000-19,000 & 27.3 & 42.9 \\
20,000-29,000 & 27.3 & 32.7 \\
30,000-39,000 & 0.0 & 14.3 \\
40,000-49,000 & 27.3 & 2.1 \\
Dependent on distance & 9.1 & 0.0 \\
Total & 100.0 & 100.0 \\
\hline
\end{tabular}

Source: Awumbila and Ardeyfio-Schandorf, (2008: 177) 
These evidences suggest that the so-called better living conditions may be unfulfilled realities. Thus contrary to the assertion that migration is a first step towards livelihood diversification (Yeboah, 2008; Ellis, 2000) the evidence presented in the preceding sections suggest that it may not always result in such pleasant outcomes as migrants strive to eke out a living at their destinations. Since living in congested rooms, poor access to essential services and lower incomes may not be indicative of good quality life, migrants cannot be said to be experiencing heaven in the cities. Destinations may have nothing to offer migrants except misery, insecurity and destitution, indicators which are uncharacteristic of well-being. It could therefore be argued that the north-south movement should not be conceived as an expression of migrant's agency to reduce poverty but rather an option that may sacrifice human dignity under the guise of pursuing well-being.

\section{Conclusion}

This paper sought to justify why internal migration may not always be a route out of poverty. Overall, it could be argued that the functional relationship between internal migration and poverty reduction is neither simple nor linear. As evident in the discussions, some migrants may get jobs (albeit menial), earn income and send remittances but such transfers may be inadequate, infrequent and may not be used for poverty reduction purposes. The absolutely poor contrariwise, may not receive remittances because of their inability to sponsor migrants. The paper reveals that there is no reason to assume that movement automatically guarantees the use of freed lands because of households' inability to raise capital to increase production. The nature of jobs moreover undermines returnees' ability to acquire skills relevant to the local economy. In addition, migrants may move into more vulnerable circumstances which in effect may increase their powerlessness and social exclusion. Based on the theoretical and empirical evidence presented in the preceding sections on the north-south migration in Ghana it could be argued that while internal migration may produce some benefits, it may not be a conventional conduit for poverty reduction because these benefits are likely to be offset by conditions which further expose migrants to perpetual deprivation and misery.

Given that the whole northern regions of Ghana are left behind in terms of benefitting from the process and outcomes of development interventions, which of course serve as one primary motivation for the movement of people to southern cities in the country, we call for establishment of manufacturing industries that could help create the needed jobs and income, investment in infrastructure and support for livelihood systems to enhance and build the productive capacity of the inhabitants of northern Ghana. This will help reduce the current wave of the north-south movement while at the same time reducing poverty in a sustainable manner. The increase in migration of the able-bodied men and women in the dry season (when crop cultivation becomes difficult) suggest that extension and expansion of existing irrigation facilities may to a large extent help reduce the rate of north-south movement. The recent increase in the number of minors in the migration stream calls for the intensification of social protection schemes such as free meals which in recent times have been saddled by problems such as lack of funds and logistics.

\section{Acknowledgment}

We will like to thank the reviewers for their constructive comments on an earlier version of the paper

\section{Author's Contributions}

Richard Serbeh: Conceptualising the overall research problem and wrote the theoretical section of the paper and typesetting.

Prince Osei-Wusu Adjei: Writing the introduction and concluding section of the paper. He contributed to offering the analytical scope of the paper.

Thomas Yeboah: Writing the case study from the Ghanaian context. He coordinated and finalised the manuscript.

\section{Ethics}

There are no foreseen ethical implications of this manuscript. The manuscript is a review and did not require ethical approval.

\section{References}

Ackah, C. and D. Medvedev, 2010. Internal migration in Ghana: Determinants and welfare impacts. Int. J. Soc. Econom., 39: 764-784.

DOI: $10.1108 / 03068291211253386$

Addae-Korankye, A., 2012. Microfinance and poverty reduction in Ghana. The case of central region of Ghana. Asian Economic Financial Rev., 2: 135-141.

Adams, R.H., 2006. Remittances and Poverty in Ghana. 1st Edn., World Bank Publications, ISBN-10: 0060131160, pp: 41.

Agyei, Y.A., E. Kumi and T. Yeboah, 2015. Is better to be a kayayei than to be unemployed: Reflecting on the role of head portering in Ghana's informal economy. GeoJournal. DOI: 10.1007/s10708-015-9620-z

Allen, J., 1979. The Growth of Ghana's Cities. 1st Edn., University of Ghana Press, Legon, Ghana. 
Anarfi, J.K., 1993. Sexuality, migration and AIDS in Ghana-a socio-behavioural study. Health Transit. Rev., 3: 45-67.

Anarfi, J.K. and S. Kwankye, 2005. The costs and benefits of children's independent migration from Northern to Southern Ghana. Proceedings of the International Conference on Childhoods: Children and Youth in Emerging and Transforming Societies, Jun. 29-Jul. 3, Oslo, Norway, pp: 57-57.

Anarfi, J.K. and S.O. Kwankye, 2009. Independent migration of children. Institute of Statistical, Social and Economic Research (ISSER), University of Ghana, Legon, Ghana.

Anh, D., C. Tacoli and H.X. Thanh, 2003. Migration in Viet Nam: A review of information on current trends and patterns and their policy implications. Proceedings of the Regional Conference on Migration, Development and Pro-Poor Policy Choices in Asia, Jun. 22-24, Bangladesh Refugee and Migratory Movements Research Unit, Bangladesh/DFID, UK, Dhaka.

Assan, J.K., C. Caminade and F. Obeng, 2009. Environmental variability and vulnerable livelihoods: Minimising risks and optimising opportunities for poverty alleviation. J. Int. Dev., 21: 403-418. DOI: $10.1002 /$ jid.1563

Awumbila, M. and E. Ardayfio-Schandorf, 2008. Gendered poverty, migration and livelihood strategies of female porters in Accra, Ghana. Norwegian J. Geography, 62: 171-179. DOI: $10.1080 / 00291950802335772$

Awumbila, M., T. Manuh, P. Quartey, C.A. Tagoe and T.A. Bosiako, 2008. Migration country paper: Ghana. Centre for Migration Studies, University of Ghana, Legon.

Aryee, J.R.A., 2000. Decentralization and Good Governance in Ghana. proceedings of the Canadian High Commission, (CHC' 00), Accra, Ghana.

Arthur, J.A., 1991. Interregional migration of Labor in Ghana, West Africa: Determinants, consequences and policy intervention. Rev. Black Political Economy, 20: 89-103. DOI: 10.1007/BF02689928

Baah-Ennumh, T.Y., O. Amponsah and M.O. Adoma, 2012. The living conditions of female head porters in the Kumasi metropolis, Ghana. J. Soc. Dev. Sci., 3: 229-244.

Bateman, M. and H.J. Chang, 2012. Microfinance and the illusion of development: From hubris to nemesis in thirty years. World Economic Review.

Baldwin, G.B., 1970. Brain drain or overflow? Foreign Affairs, 48: 358-372. DOI: 10.2307/20039447

Bhasin, V.K. and S.K. Annim, 2005. Impact of Elimination of Trade Taxes on Poverty and Income Distribution in Ghana. In: Macroeconomic Policy Challenges in Low Income Countries, IMF (Eds.), IMF, Washington, DC, pp: 1-42.
Caldwell, J.C., 1968. Determinants of rural-urban migration in Ghana. Population Studies: J. Demography, 22: 361-377. DOI: $10.1080 / 00324728.1968 .10404945$

Castaldo, A., P. Deshingkar and A. McKay, 2012. Internal migration, remittances and poverty: Evidence from Ghana and India. University of Sussex, Migrating Out Of Poverty Working Paper, Falmer.

Crawford, G., 2004. Democratic decentralization in Ghana: Issues and prospects. POLIS Working Paper, School of Politics and International Studies.

de Haan, A. and S. Yaqub, 2009. Migration and poverty: Linkages, knowledge gaps and policy implications. Proceedings of the Social Policy and Migration in Developing Countries, Nov. 22-23, Stockholm.

de Haas, H., 2010. Migration and development: A theoretical perspective. Int. Migrat. Rev., 33: 227-264. DOI: $10.1111 /$ j.1747-7379.2009.00804.x

Deshingkar, P. and S. Grimm, 2005. Internal migration and development: A global perspective.

Dang, N.A., 2003. Internal migration policies in the ESCAP region. Asia-Pacific Populat. J., 18: 27-40.

Ellis, F., 2000. Rural Livelihoods and Diversity in Developing Countries. 1st Edn., Oxford University Press, Oxford, ISBN-10: 0198296967, pp: 273.

GD, 2012. Profile of tamale metropolitan area. Ghana Districts.

GSS, 2005. Ghana 2003 Core Welfare Indicators Questionnaire (CWIQ II) survey report-Statistical Abstract. Ghana Statistical Service, Accra.

GSS, 2014. Ghana living standard survey 6: Poverty profile report. Ghana Statistical Service.

GSS, 2008. Ghana living standards survey Report of the fifth round. Ghana Statistical Service.

GSS, 2007. Pattern and trends of poverty in Ghana, 1991-2006. Ghana Statistical Service, Accra.

Grant, R. and J. Nijman, 2004. The re-scaling of uneven development in Ghana and India. Tijdschrift Voor Economische en Sociale Geografie, 95: 467-481. DOI: $10.1111 / \mathrm{j} .0040-747 X .2004 .00333 . \mathrm{x}$

Hesselberg, J. and J.A. Yaro, 2006. An assessment of the extent and causes of food insecurity in Northern Ghana using a livelihood vulnerability framework. GeoJournal, 67: 41-55. DOI: $10.1007 / \mathrm{s} 10708-006-9007-2$

Huijsmans, R., 2008. Children working beyond their localities: Lao children working in Thailand. Childhood, 15: 331-352. DOI: $10.1177 / 0907568208091667$

IOM, 2005. Development and poverty reduction in Asia. IOM.

Keely, C. and B.N. Tran, 1989. Remittances from Labor migration: Evaluations, performance and implications. Int. Migrat. Rev., 23: 500-525. DOI: 10.2307/2546426 
Kwankye, S.O., J.K. Anarfi, C.A. Tagoe and A. Castaldo, 2007. Coping strategies of independent child migrants from Northern Ghana to Southern cities. Working Paper T-23, Development Research Centre on Migration, Globalisation and Poverty, University of Sussex. Sussex, UK.

Lipton, M., 1980. Migration from rural areas of poor countries: The impact on rural productivity and income distribution. World Dev., 8: 1-24. DOI: 10.1016/0305-750X(80)90047-9

Mensah-Bonsu, A., 2003. Migration and Environmental Pressure in Northern Ghana. 1st Edn., Vrije Universiteit, Amsterdam.

MPRPC, 2011. Internal migration and poverty: Evidence from Ghana and India. Migrating Poverty Research Programme Consortium.

Marchetta, F., 2011. On the move livelihood strategies in Northern Ghana. CERDI, Etudes et Documents.

Narayan, D., R. Patel, K. Schafft, A. Rademacher and S. Koch-Schulte, 2000. Voices of the poor: Can anyone hear us? World Bank, Washington DC.

Nukunu, P.E., 2013. Fight against Streetism in Ghana.

Opare, J.A., 2003. Kayayei: The women head porters of Southern Ghana. J. Soc. Dev. Africa, 18: 33-48.

Ping, H. and Z. Shaohua, 2005. Internal migration in China: Linking it to development. International Organization for Migration (2005), Migration, Development and Poverty Reduction in Asia, Academic Foundation.

Quaicoe, R., 2005. Woes of the Kayayoo. The Daily Graphic.

Ribot, J.C., 2001. Local actors, powers and accountability in African decentralizations: A review of issues UNRISD.

Shamsu-Deen, Z., 2013. Migrattion and health nexus: A case of female porters (Kayayei) in Accra, Ghana. Res. Humanit. Soc. Sci., 3: 103-109.

Shamsu-Deen, Z. and M. Alhassan, 2014. Beyond the Cedis: Migration and reproductive health among female potters in Accra. ABC Res. Alert, 2: 1-18.

Songsore, J. and G. McGranahan, 1993. Environment, wealth and health: Towards an analysis of intraurban differentials within the greater Accra metropolitan area, Ghana. Environ. Urbanizat., 5: 10-34. DOI: $10.1177 / 095624789300500203$

Srivastava, R. and S.K. Sasikumar, 2003. An overview of migration in India, its impacts and key issues. Proceedings of the Migration, Development and Pro-poor Policy Choices in Asia, Regional Conference, (ARC' 03), Refugee and Migratory Movements Research Unit/DFID, Dhaka, Bangladesh.
Stark, O., 1991. The Migration of Labor. 1st Edn., B. Blackwell, Cambridge, ISBN-10: 1557860300, pp: 406.

UN, 2005. UN millennium project, investing in development: A practical plan to achieve the millennium development goals. UN, New York. International Organization for Migration (2005). Migration, Development and Poverty Reduction in Asia, Academic Foundation.

UN-HABITAT, 2011. Ghana housing profile. UNHABITAT, Nairobi, Kenya.

WFP, 2013. Comprehensive food security and vulnerability analysis Ghana 2012: Focus on Northern Ghana. World Food Programme, Rome.

Wouterse, F., 2010. Internal migration and rural service provision in Northern Ghana.

WB, 2011. Republic of Ghana, tackling poverty in Northern Ghana. Report No. 53991-Gh, World Bank Washinton DC.

Yaro, A.J., 2006. Is deagrarianisation real? A study of livelihood activities in rural northern Ghana. J. Modern African Stud., 44: 125-156. DOI: $10.1017 / \mathrm{S} 0022278 \mathrm{X} 05001448$

Yeboah, R.N., 2005. Climate variability and small farmer's economic decision making processes: The case of bongo district, Upper East Region, Ghana. Ph.D. dissertation, University of Ghana.

Yeboah, M.A., 2008. Gender and livelihoods: Mapping the economic strategies of porters in Accra, ProQuest, Ghana.

Yeboah, T., L. Owusu, A. Arhin and E. Kumi, 2015. Fighting poverty from the street: Perspectives of some female informal sector workers on gendered poverty and livelihood portfolios in Southern Ghana. J. Economic Soc. Stud., 5: 239-267.

DOI: $10.14706 /$ JECOSS1 1511

Yiran, G.S.A., J.K. Teye and G.A. Yiran, 2014. Accessibility and utilisation of maternal health services by Migrant female head porters in Accra. J. Int. Migrat. Integrat., 16: 929-945. DOI: $10.1007 / \mathrm{s} 12134-014-0372-2$ 